\title{
Diversity and abundance of ammonia-oxidizing Archaea and Bacteria in tropical and cold-water coral reef sponges
}

\author{
Joana F. M. F. Cardoso ${ }^{1,2, *}$, Judith D. L. van Bleijswijk ${ }^{1}$, Harry Witte ${ }^{1}$, \\ Fleur C. van Duyl ${ }^{1}$ \\ ${ }^{1}$ NIOZ Royal Netherlands Institute for Sea Research, PO Box 59, 1790 AB Den Burg Texel, The Netherlands \\ ${ }^{2}$ CIIMAR/CIMAR Interdisciplinary Centre of Marine and Environmental Research, University of Porto, \\ Rua dos Bragas 289, 4050-123 Porto, Portugal
}

\begin{abstract}
We analysed the diversity and abundance of ammonia-oxidizing Archaea (AOA) and Bacteria (AOB) in the shallow warm-water sponge Halisarca caerulea and the deep cold-water sponges Higginsia thielei and Nodastrella nodastrella. The abundance of AOA and AOB was analysed using catalyzed reporter deposition-fluorescence in situ hybridization and (real-time) quantitative PCR (Q-PCR) targeting archaeal and bacterial amoA genes. Archaeal abundance was similar between sponge species, while bacterial abundance was higher in $H$. caerulea than in $N$. nodastrella and $H$. thielei. Q-PCR showed that AOA outnumbered AOB by a factor of 2 to 35, suggesting a larger role of AOA than of AOB in ammonia oxidation in sponges. PCR-denaturing gradient gel electrophoresis was performed to analyse the taxonomic affiliation of the microbial community associated with these sponges. Archaeal and bacterial amoA genes were found in all 3 sponges. The structure of the phylogenetic trees in relation to temperature and sponge species was analysed using all published amoA sequences retrieved from sponges. Temperature was an important factor influencing the distribution of nitrifiers in sponges. Both archaeal and bacterial amoA sponge sequences tended to cluster with sequences retrieved from habitats of similar temperature. This is the first time that similarity in AOB diversity is described between distantly related species $(H$. thielei belonging to the class Demospongiae, and $N$. nodastrella to Hexactinellida). The results described here support the idea of a relatively uniform microbial community between distantly related sponges and suggest that temperature (rather than phylogenetic distance) is determining the diversity of $\mathrm{AOA}$ and $\mathrm{AOB}$ in sponges.
\end{abstract}

KEY WORDS: amoA gene $\cdot$ Archaea $\cdot$ Bacteria $\cdot$ Temperature $\cdot$ Marine $\cdot$ Sponges Resale or republication not permitted without written consent of the publisher

\section{INTRODUCTION}

Nitrification is the first step in the nitrogen cycle, involving the oxidation of ammonia $\left(\mathrm{NH}_{3}\right)$ to nitrite $\left(\mathrm{NO}_{2}{ }^{-}\right)$and subsequently to nitrate $\left(\mathrm{NO}_{3}{ }^{-}\right)$. These 2 steps are catalysed by distinct groups of microorganisms: ammonia oxidizers and nitrite oxidizers. It is now well established that some marine sponges (phylum Porifera) live in association with microorganisms which are able to nitrify (Corredor et al. 1988, Diaz \& Ward 1997, Diaz et al. 2004, Jiménez \& Ribes 2007, Taylor et al. 2007, Southwell et al. 2008, Van Duyl et al. 2008, Hoffmann et al. 2009, Schläppy et al. 2010, Hentschel et al. 2012). Ammonia-oxidizing Bacteria (AOB) and nitrite-oxidizing Bacteria (NOB) have been observed in sponges (Taylor et al. 2007 and references therein). Ammonia-oxidizing Archaea (AOA) have also been receiving increasing attention since 
the discovery of the ammonia-oxidizing thaumarchaeote Cenarchaeum symbiosum associated with the sponge Axinella mexicana (Preston et al. 1996). Thaumarchaeotes, in particular, appear capable of oxidizing ammonia (Bayer et al. 2008, Turque et al. 2010, Liu et al. 2011, Pester et al. 2011 and references therein). Recently, the presence of AOB and AOA was described for a diverse range of sponges from the Pacific, Caribbean, Mediterranean and North Atlantic (Bayer et al. 2008, Meyer \& Kuever 2008, Steger et al. 2008, López-Legentil et al. 2010, Mohamed et al. 2010, Liu et al. 2011, Radax et al. 2012). Nitrification by sponges may well be significant in coral reef ecosystems, considering the high biomass of sponges in such systems (Diaz \& Rützler 2001, Reitner \& Hoffmann 2003, Van Soest et al. 2007a).

The tropical shallow-water sponge Halisarca caerulea (Vacelet \& Donadey 1987) (class Demospongiae, order Halisarcida, family Halisarcidae) and the cold deep-water sponges Higginsia thielei (Topsent, 1898) (class Demospongiae, order Halichondrida, family Heteroxyidae) and Nodastrella nodastrella (until recently known as Rossella nodastrella Topsent, 1915; Dohrmann et al. 2012) (class Hexactinellida, order Lyssacinosida, family Rossellidae) are common inhabitants of Atlantic coral reefs. Nitrification has been reported in the latter 2 species, most likely being mediated by sponge-associated microbes (Van Duyl et al. 2008). H. thielei and N. nodastrella harbor relatively high amounts of Archaea and Bacteria (ca. 7 to $30 \%$ Archaea and 36 to $65 \%$ Bacteria of the total microbial counts with DAPI staining; Van Duyl et al. 2008). Furthermore, evidence for microbial bicarbonate fixation by these sponges in the dark ocean suggests that spongeassociated microorganisms may be involved in ammonia oxidation in these areas. H. caerulea also harbours sponge-associated microorganisms (De Goeij et al. 2008). This sponge lives in cryptic habitats in the reef, like crevices, which have shown net release of nitrate (Van Duyl et al. 2006). Since sponges cover up to $50 \%$ of the calcareous rock in these crevices (Scheffers et al. 2004) and several tropical reef sponges have already been reported to nitrify (e.g. Corredor et al. 1988, Diaz \& Ward 1997, Southwell et al. 2008), it is assumed that the measured nitrate efflux was at least partly coming from cavity sponges including $H$. caerulea. Despite these suggestions, it is still unknown whether microorganisms associated to $H$. caerulea, $H$. thielei and $N$. nodastrella could be directly involved in the $\mathrm{N}$-cycle. 16S rRNA genes and the ammonia-monooxygenase subunit A (amoA) gene have been commonly used to detect the presence of ammonia-oxidizing microorganisms in sponges (see Taylor et al. 2007 and references therein, Bayer et al. 2008, Cheng et al. 2008, Meyer \& Kuever 2008, Mohamed et al. 2008, 2010, Steger et al. 2008, Hoffmann et al. 2009).

Ammonia-monooxygenase (AMO) is an integral membrane protein occurring in ammonia oxidizers, which is composed of 3 subunits (A, B and C) and various metal centres (Hyman \& Arp 1992, McTavish et al. 1993, Klotz et al. 1997). The amoA subunit contains the active site of AMO (Hyman \& Arp 1992). Despite the fact that fewer studies have used amoA when compared to $16 \mathrm{~S}$ rRNA, the amoA gene has the advantage that it encodes a protein involved directly in ammonia oxidation and is, therefore, a functional gene important to the nitrification process (O'Mullan $\&$ Ward 2005). In the present study, we analysed the diversity and abundance of the amoA functional gene in Higginsia thielei, Nodastrella nodastrella and Halisarca caerulea with the aim of assessing whether (1) these sponge species harbour bacterial and archaeal nitrifiers and (2) the diversity of the ammonia-oxidizing microbial community is mainly sponge related or temperature related. Since this study includes sponges belonging to different taxonomic classes (1 hexactinellid sponge and 2 demosponges), the diversity of AOA and AOB associated with phylogenetically distant host sponges was also analysed.

Here, 'sponge-associated' microorganism refers merely to the presence of a certain microorganism in the sponge, assuming nothing regarding the existence of interaction or dependence.

\section{MATERIALS AND METHODS}

\section{Study site, species and sampling}

The marine sponge Halisarca caerulea is a thin encrusting sponge living in coral cavities and common in shallow waters ( 2 to $25 \mathrm{~m}$ ) of the Caribbean Sea (Vacelet \& Donadey 1987, Collin et al. 2005, De Goeij et al. 2008). H. caerulea were carefully chiselled out of coral cavities under coral slabs or coral rock overhangs on the forereef slope of Curaçao, southern Caribbean. Material was collected between 15 and $17 \mathrm{~m}$ depth from the walls of dead end cavities of 50 to 2501 volume at the Carmabi reef (Buoys 0 and 1) in February 2003 and at Blue Bay in April to May 2004. In addition, samples of 2 to 31 of water surrounding the sponges were collected (for details of collected samples see Table S1 in the supplement at 
www.int-res.com/articles/suppl/a068p215_supp.pdf). Water samples were first pre-filtered through a $0.8 \mu \mathrm{m}$ pore size polycarbonate filter (Poretics) and then filtered through a $0.2 \mu \mathrm{m}$ pore size polycarbonate filter (Poretics). Filters were wrapped in clean aluminium foil and kept frozen at $-80^{\circ} \mathrm{C}$ until DNA extraction. Total DNA was extracted as described below.

The marine sponges Higginsia thielei and Nodastrella nodastrella are present in deep-water coral mounds (up to $>1000 \mathrm{~m}$ depth) off the Azores and in the south-eastern Rockall Bank, in the North East Atlantic (Van Soest et al. 2007b, 2012). H. thielei is a small, round and rigid sponge, while $N$. nodastrella is a large, thin-walled, tubular, trumpet-shaped sponge (Van Soest et al. 2007a,b). These sponges were collected on the south-eastern part of Rockall Bank (Logachev mounds) from 24 June to 12 July 2006 with a box corer (stainless steel cylindrical barrel: $50 \mathrm{~cm}$ inner diameter, $55 \mathrm{~cm}$ high) at a depth between 558 and $578 \mathrm{~m}$ (for details on methodology see Van Duyl et al. 2008). Due to the large size of $N$. nodastrella, 2 to 3 samples per box core were taken; these were considered to belong to the same colony. In the case of $H$. thielei, each sample corresponded to a different colony (Table S1 in the supplement).

The species names of sponges were determined on the basis of morphological characteristics, spicula morphology and composition (Van Soest 1978, Kobluk \& Van Soest 1989, Hooper \& Van Soest 2002).

\section{Microbial abundance in sponges and surrounding seawater}

Sponge samples of 6 specimens of Halisarca caerulea were fixed with paraformaldehyde $(4 \mathrm{~g}$ per $100 \mathrm{ml}$ ) in phosphate-buffered saline solution (1x PBS) for up to $12 \mathrm{~h}$ at $4^{\circ} \mathrm{C}$. After washing twice with $1 \times$ PBS, samples were stored in a PBS/80\% ethanol mixture $(1: 1)$ at $-20^{\circ} \mathrm{C}$. To determine the microbial abundance in the sponge tissue, a small piece of sponge $\left(0.5 \mathrm{~cm}^{2}\right.$ and $2 \mathrm{~mm}$ thick) representing a volume of ca. $100 \mathrm{~mm}^{3}$ was crushed with a rubber stick in a reaction vial containing $200 \mu$ l Lysis $\mathrm{T}$ solution (Sigma-Aldrich) to dissociate the sponge tissue and release the microbial cells. Subsequently, several washing steps with artificial seawater (ASW) and centrifuging were conducted to collect microorganisms in the supernatant. Pellets were checked on filters for remaining microorganisms with 4',6diamidino-2-phenylindole (DAPI). From the water surrounding $H$. caerulea, 7 samples were taken and fixed with $37 \%$ formaldehyde (final concentration:
$2 \%$ ). Microorganisms in the supernatant, as well as samples from the water surrounding the sponge, were collected on GTTP filters $(0.2 \mu \mathrm{m}, 25 \mathrm{~mm}$ diameter) and stained according to the catalyzed reporter deposition-fluorescence in situ hybridization (CARD-FISH) protocol by Pernthaler et al. (2002). The following probes were applied for targeting Bacteria: EUB338 (Amann et al. 1990), EUBmix (mixture of EUB338, EUB338II and EUB338 III; Daims et al. 1999) and NonEUB338 (an oligonucleotide probe which is complementary to the probe EUB338 and serves as a control for non-specific binding; Wallner et al. 1993). For targeting Archaea the following probes were used: EURY806 (Euryarchaea) and Cren 537 (Crenarchaea, now Thaumarchaea) (Teira et al. 2004).

In short, the protocol comprises the following steps. (1) Cells were embedded in the filter by dipping them into low-gelling-point $0.1 \%$ agarose and drying them upside down in a Petri dish, followed by a dehydration step with $95 \%$ ethanol. (2) Cell walls were made permeable by incubation in a solution of lysozyme for Bacteria and proteinase $\mathrm{K}$ for Archaea during $1 \mathrm{~h}$ at $37^{\circ} \mathrm{C}$. Filters were washed with Milli-Q and incubated in $0.01 \mathrm{M} \mathrm{HCl}$ at room temperature for 20 min (Teira et al. 2004), and filters were cut into sections to allow incubations with different solutions and probes. (3) A hybridization buffer was used, containing $55 \%$ formamide for EUB and NonEUB probes and $20 \%$ formamide for archaeal probes. Hybridization took place in the dark at $35^{\circ} \mathrm{C}$ for $14 \mathrm{~h}$. (4) Fluorescent dye (tyramide-Alexa488) was added to amplify the signal by incubating the samples for $45 \mathrm{~min}$ at $37^{\circ} \mathrm{C}$. After amplification, filter pieces were washed in PBS-T $(0.05 \%$ Triton) in the dark at room temperature for 25 min, followed by washing with Milli-Q and dehydration with $95 \%$ ethanol. When filters were dry, they were mounted in a drop of DAPI-mix (DAPI solution in $1 \times$ PBS with Vectashield and Citifluor anti-fading reagents) on a glass slide and stored at $-20^{\circ} \mathrm{C}$. Slides were analysed with an epifluorescent Zeiss Axioplan microscope. For quantification of bacterial cells, 6 filter sections were analysed for Halisarca caerulea and 7 for the surrounding water. For quantification of archaeal cells, 4 filter sections were analysed for $H$. caerulea and 2 for the surrounding water. Total counts (DAPI) and specific probe counts were made in 20 randomly selected fields per filter section. Per filter section, $>400$ microorganisms were counted for DAPI and EUB probes and $>70$ for EURY and CREN probes (for an example see Fig. S1 in the supplement at www.int-res.com/articles/suppl/a068p215_supp. pdf). To circumvent problems related to auto-fluores- 
cence, a double-labelled NonEUB338 probe (Wallner et al. 1993) was applied on a separate filter section and visualized under the same conditions as described above for the CARD-FISH protocol. No signals were detected with the NonEUB338 probe, indicating that all signals detected with the EUB338 probe were Bacteria. Microbial abundance in $H$. caerulea and the surrounding water was compared with data from Van Duyl et al. (2008) on microbial abundance in Nodastrella nodastrella, Higginsia thielei and the surrounding water.

\section{DNA extraction}

DNA was extracted from ethanol-preserved sponges (5 samples of Halisarca caerulea, 4 samples of Higginsia thielei and 8 samples of Nodastrella nodastrella) and water sample filters surrounding $H$. caerulea (2 samples) using the UltraClean Soil DNA isolation kit (Mo Bio). About $2 \mathrm{~mm}^{3}$ of sponge was grinded with a mortar in Lysis solution (UltraClean Soil DNA isolation kit, Mo Bio). Resulting cell suspension was added to the tube with mineral beads, and DNA extraction was done according to the Mobio kit's protocol for maximum yield, involving 10 min of bead beating and binding of the DNA to a silica column. Filters of water samples were cut into small pieces with sterile scissors and processed in a similar way as the sponges.

\section{PCR for DGGE-sequencing}

Amplification of bacterial and archaeal amoA genes was performed using 2-step amplification protocols. For Bacteria, the PCR protocol and the primers were used as described by Hornek et al. (2006), with modifications: in $20 \mu \mathrm{l}$ reactions we used $10 \mathrm{pmol}$ of each degenerate primer amoA-1F (5'-GGG GHT TYT ACT GGT GGT-3'; H = not G, Y = T or C) and amoAr NEW (5'-CCC CTC BGS AAA VCC TTC TTC-3'; $\mathrm{S}=\mathrm{G}$ or $\mathrm{C}, \mathrm{V}=\mathrm{G}$ or $\mathrm{A}$ or $\mathrm{C}, \mathrm{B}=\mathrm{C}$ or $\mathrm{G}$ or $\mathrm{T})$, 1 U Picomaxx enzyme and $1 \times$ Picomaxx buffer (Stratagen), $5 \mathrm{nM}$ of each dNTP and $8 \mu \mathrm{g}$ of bovine serum albumin (BSA) for the first step amplification. The annealing temperature was increased to $60^{\circ} \mathrm{C}$ for maximum specificity, and a total of 33 cycles were run to generate template for the second reaction. The second step was performed with a GC-clamp on the forward primer amoA-1F and with the inosine primer amoAr-i (5' - CCC CTC iGi AAA iCC TTC TTC-3'; i = inosin) in order to reduce complex band patterns in the denaturing gradient gel electrophoresis (DGGE). For this second reaction, we added $1 \mathrm{U}$ of Genescript taq polymerase, $\mathrm{MgCl}_{2}$ to a final concentration of $2.0 \mathrm{mM}$ and $5 \mathrm{pmol}$ of each primer. We ran 20 cycles with an annealing temperature of $60^{\circ} \mathrm{C}$ and added a final 30 min extension step.

For Archaea, the PCR protocol and the primers were described by Wuchter et al. (2006). For the first PCR step, we used 4 pmol of each primer ArchamoA-for (5'-CTG AYT GGG CYT GGA CAT C-3') and Arch-amoA-rev (5'-TTC TTC TTT GTT GCC CAG TA -3'), 1 U Picomaxx enzyme, $5 \mathrm{nM}$ of each $\mathrm{dNTP}$ and $8 \mu \mathrm{g}$ BSA. The annealing temperature was $57^{\circ} \mathrm{C}$. The second step was performed with a GCclamp on the reverse primer (Arch-amoA-rev) and with a newly developed inosine variant of the ArchamoA-for primer, amoAf-i-BA (5'-CTG AiT GGG CiT GGA CAT C-3'; present paper). This was done to reduce the complexity of the DGGE banding pattern (Hornek et al. 2006). Conditions were as described for the second step of bacterial amoA amplification, except for an optimized annealing temperature of $51.8^{\circ} \mathrm{C}$

\section{DGGE}

DGGE for Bacteria was performed as described by Hornek et al. (2006), by using approximately $100 \mathrm{ng}$ of the product from the second step PCR on a 20 to $80 \%$ urea-formamide (UF) denaturing gradient gel. For Archaea, DGGE was performed as described by Wuchter et al. (2006) by using around $100 \mathrm{ng}$ of the product from the second step PCR on a 10 to $50 \%$ UF denaturing gradient gel. Electrophoresis was performed using a D-Code system (Bio-Rad) with $1 \times$ Tris-acetate-EDTA (TAE) buffer (pH 8.3) at a constant temperature of $55^{\circ} \mathrm{C}$ and a voltage of $10 \mathrm{~V}$ for $10 \mathrm{~min}$ plus $200 \mathrm{~V}$ for $5 \mathrm{~h}$ for Bacteria, and at a constant temperature of $60^{\circ} \mathrm{C}$ and a voltage of $10 \mathrm{~V}$ for $15 \mathrm{~min}$ plus $200 \mathrm{~V}$ for $3 \mathrm{~h}$ for Archaea. Gels were stained with a solution of $2 \times$ SYBR gold in $1 \times$ TAE to visualize banding patterns. All clear bands in each sample were excised from the gel. Excised bands were soaked in $50 \mu \mathrm{l}$ sterile $10 \mathrm{mM}$ TRIS-buffer $(\mathrm{pH}$ 8.0) for a minimum of $48 \mathrm{~h}$ at $4^{\circ} \mathrm{C}$. Of this $50 \mu \mathrm{l} \mathrm{vol-}$ ume, $0.4 \mu \mathrm{l}$ was used in a re-amplification reaction according to the protocols described for the secondstep PCR, but without GC-clamps.

For cycle-sequencing reactions, we used the Big Dye Terminator solution V1.1 (Applied Biosystems). Products were analyzed on the ABI prism 310 genetic analyzer. 


\section{Sequence analyses}

Electropherograms were inspected manually for ambiguities. If the height of a second peak was at least $50 \%$ of the highest peak then the ambiguity was uncorrected. In addition, when sequences with double peaks were seen, these were always due to a combination of 2 sequences (without double peaks) present lower in the gel; therefore, double peak sequences were discarded. Consensus sequences (assembled forward and reverse sequences) were aligned using the BLAST algorithm (Altschul et al. 1997) and, together with their close relatives, imported into the program ARB (Ludwig et al. 2004). Other relevant marine amoA sequences present in GenBank were also imported. A multiple alignment was made of the nucleotide sequences. Nucleotide sequences were translated into amino-acid sequences which could be easily aligned. No gaps were found in the alignment of amino-acid sequences; therefore, the nucleotide sequences were aligned accordingly. Different nucleotide and protein sequences were considered when $>1$ substitution was found compared to another sequence in the database.

Non-redundant bacterial amoA nucleotide sequences from this study $(\mathrm{n}=17)$ were compared with all non-redundant bacterial nucleotide sequences from marine sponges, sequences from water and sediment, and from cultivated Nitrosomonas spp. and Nitrosospira spp., available in GenBank (date of September 2012). In total, 115 nucleotide sequences were considered. The backbone was constructed using 105 sequences with 387 informative positions and was analysed with Rapid Maximum-Likelihood (RaxML-VI Version 2.2.1; Stamatakis 2006) and neighbour-joining (NJ) algorithms implemented in ARB. Trees were calculated to visualize the affiliation of the derived sequences. Other (shorter) sequences were added to the reference tree using ARB parsimony, starting with the longest sequence and ending with the shortest (377 to $387 \mathrm{bp}$, from Dysidea avara; Ribes et al. 2012), using the respective sequence as a filter. Bootstrap analyses (1000 runs for NJ and 100 runs for RaxML) were used to estimate the support of the affiliations.

Non-redundant archaeal amoA nucleotide sequences from this study $(\mathrm{n}=14)$ were compared with nonredundant sequences present in Genbank (date of September 2012) of other marine sponge-associated Archaea, including 'Candidatus Cenarchaeum symbiosum' (Hallam et al. 2006), of water, sediment and corals, and of Nitrosopumilus maritimus (Könneke et al. 2005). In total, 158 nucleotide sequences were con- sidered. The backbone, consisting of 130 sequences of $550 \mathrm{bp}$, was used to construct the tree topology using RaxML and NJ algorithms with bootstrap analyses (100 and 1000 replicates, respectively). Then, 28 shorter sequences (161 to $217 \mathrm{bp}$, including our own sequences) were inserted in the reference tree via ARB Parsimony, one by one, starting with the longest sequence.

Sequence data have been submitted to the GenBank database under Accession Numbers GQ353375 to GQ353399 and GQ353427 for Bacteria ( $\mathrm{n}=26$ ), and GQ353400 to GQ353426 for Archaea ( $\mathrm{n}=27$ ).

\section{Q-PCR analysis}

Quantification of archaeal and bacterial amoA gene copies in samples from Halisarca caerulea (5 samples) and the surrounding water (2 samples), Higginsia thielei (4 samples) and Nodastrella nodastrella (7 samples) were performed by (real-time) quantitative PCR (Q-PCR) analysis using primers described by Wuchter et al. (2006) for Archaea and by Hornek et al. (2006) for Bacteria (see previous subsections). Cycling conditions were the ones described above for PCR reactions. The reactions were performed in a CFX96 system (Bio-Rad, Hercules). Calibration curves were prepared from the nearly complete amoA gene of Nitrosopumillus maritimus (940 bp; dilution series: 1 to $1 \times 10^{7}$ copies per microlitre) and from a partial fosmid of the amoA gene of Nitrosomonas eutropha (490 bp; dilution series: 1 to $1 \times 10^{7}$ copies per microlitre). Efficiency was $88 \%\left(\mathrm{r}^{2}=0.99\right.$, linear standard curve over 7 decades) for the archaeal amoA gene and $67 \%\left(r^{2}=0.98\right.$, linear standard curve over 6 decades) for the bacterial amoA gene. All DNA extracts were analysed in triplicate. No samples were excluded from the analysis.

\section{Statistical analysis}

To analyse the structure of the phylogenetic trees in relation to temperature (warm, cold, temperate) and sponge species, distance matrixes were exported from ARB into the PRIMER 6.1.7 software package (Primer-E Ltd). Within PRIMER, non-parametric permutation tests (ANOSIM, analysis of similarity) were done according to Clarke (1993). Two-way nested ANOSIMs were performed to test the null hypotheses that there is no structure in, respectively, AOA and $\mathrm{AOB}$ communities between different temperatures, considering differences in AOA and AOB community structure related to different sponge species. Because 
the interpretation of ANOSIM results has limitations (e.g. it is based on ranks) 2-way nested PERMANOVA tests (permutational multivariate analysis of variance) were conducted as well. For that, PERMANOVA+ add-on package was used in PRIMER (Anderson et al. 2008). Monte Carlo (MC) sampling was used to stress the problem of limited possible permutations. Because of the unbalanced design, tests were done using Type III sums of squares. Additional PERMANOVA tests were conducted to test whether the distribution of $\mathrm{AO}$ microorganisms was related to their substrate (sponge, coral, water, sediment).

\section{RESULTS}

\section{Abundance of AOA and $\mathrm{AOB}$}

Total microbial abundance (DAPI) in Halisarca caerulea was on average $12.3 \times 10^{8} \pm 7.1 \times 10^{8}(\mathrm{SD})$ $\mathrm{cm}^{-3}$ of sponge (Table 1). For comparison, cell abundance data for Higginsia thielei and Nodastrella nodastrella collected in 2005 at the same locations as in the present study (Van Duyl et al. 2008) are also presented in Table 1. Total microbial abundance was higher in $H$. caerulea than in $H$. thielei $\left(2.0 \times 10^{8} \pm 1.4\right.$ $\left.\times 10^{8}\right)$ and $N$. nodastrella $\left(2.5 \times 10^{8} \pm 1.1 \times 10^{8}\right)$. CARD-FISH results revealed that the abundance of sponge-associated Bacteria was higher in $H$. caerulea $\left(9.7 \times 10^{8} \pm 6.3 \times 10^{8}\right)$ than in the 2 cold-water species $\left(1.0 \times 10^{8}\right.$ to $\left.1.4 \times 10^{8}\right)$, while the abundance of sponge-associated Archaea (Euryarchaea + Thaumarchaea, i.e. total Archaea) was comparable between H. caerulea $\left(0.2 \times 10^{8} \pm 0.1 \times 10^{8}\right)$ and the 2 other species $\left(0.3 \times 10^{8}\right.$ to $0.4 \times 10^{8}$ total Archaea $\mathrm{cm}^{-3}$ of sponge) (Table 1). Numbers of Thaumarchaea were slightly lower in $H$. caerulea $\left(0.06 \times 10^{8} \pm 0.05 \times 10^{8}\right)$ than in $N$. nodastrella and $H$. thielei $\left(\sim 0.2 \times 10^{8}\right)$. About $25 \%$ of the DAPI counts of sponge-associated microorganisms could not be identified with the bacterial and archaeal CARD-FISH probes applied. The concentration of microorganisms was (1000x) higher in the sponge tissues than in the surrounding water. Thaumarchaeota were $(10 \times)$ more abundant in water surrounding $N$. nodastrella and $H$. thielei than in water around $H$. caerulea (Table 1).

Q-PCR results showed that there were always more (2 to 35 ) archaeal amoA copies than bacterial amoA copies in the tested sponges (Table S2 in the supplement at www.int-res.com/articles/suppl/a068 p215_supp.pdf), suggesting a larger role of AOA than of $\mathrm{AOB}$ in ammonia oxidation in sponges. On average, AOA/AOB ratios in the tropical sponge Halisarca caerulea (mean ratio $=5$; individual ratios: 2 to $10 \pm 1$ to $3 \mathrm{SD}$ ) were lower than in the cold-water sponges Higginsia thielei (mean ratio $=16$; individual ratios: 4 to $25 \pm 1$ to $5 \mathrm{SD}$ ) and Nodastrella nodastrella ( mean ratio $=11$; individual ratios: 4 to $35 \pm 1$ to $6 \mathrm{SD}$ ). Bacterial amoA copies in the water surrounding $H$. caerulea were below the detection limit in 1 of the 2 samples. In the water sample where bacterial amoA was detected, archaeal amoA copies were $81 \pm 9$ (SD) times higher than bacterial amoA copies (Table S2).

\section{Diversity of sponge-associated AOA}

The tropical sponge Halisarca caerulea hosted a higher diversity of archaeal amoA (8 different nucleotide sequences) than the cold-water sponges

Table 1. Calculated number (n) of Bacteria, total Archaea (Euryarchaea + Thaumarchaea) and Thaumarchaea related to total microbial counts (DAPI) in Halisarca caerulea, Higginsia thielei and Nodastrella nodastrella $\left(\mathrm{n} \mathrm{cm}^{-3}\right)$, and in the water $\left(\mathrm{n} \mathrm{ml}{ }^{-1}\right)$. Standard deviations for $H$. caerulea data are in parentheses

\begin{tabular}{|c|c|c|c|c|c|}
\hline Type & Temperature & Microbial counts & Bacteria & Total Archaea & Thaumarchaea \\
\hline \multicolumn{6}{|l|}{ Sponge } \\
\hline H. caerulea & Warm & $\begin{array}{c}12.28 \times 10^{8} \\
\left(7.14 \times 10^{8}\right)\end{array}$ & $\begin{array}{c}9.71 \times 10^{8} \\
\left(6.34 \times 10^{8}\right)\end{array}$ & $\begin{array}{c}0.15 \times 10^{8} \\
\left(0.11 \times 10^{8}\right)\end{array}$ & $\begin{array}{c}0.06 \times 10^{8} \\
\left(0.05 \times 10^{8}\right)\end{array}$ \\
\hline H. thielei ${ }^{\text {a }}$ & Cold & $2.00 \times 10^{8}$ & $0.96 \times 10^{8}$ & $0.36 \times 10^{8}$ & $0.24 \times 10^{8}$ \\
\hline N. nodastrella ${ }^{\mathrm{a}}$ & Cold & $2.53 \times 10^{8}$ & $1.39 \times 10^{8}$ & $0.28 \times 10^{8}$ & $0.23 \times 10^{8}$ \\
\hline \multicolumn{6}{|l|}{ Ambient water } \\
\hline H. caerulea & Warm & $\begin{array}{c}11.01 \times 10^{5} \\
\left(1.59 \times 10^{5}\right)\end{array}$ & $\begin{array}{c}5.77 \times 10^{5} \\
\left(1.80 \times 10^{5}\right)\end{array}$ & $\begin{array}{c}0.14 \times 10^{5} \\
\left(0.11 \times 10^{5}\right)\end{array}$ & $\begin{array}{c}0.004 \times 10^{5} \\
\left(0.004 \times 10^{5}\right)\end{array}$ \\
\hline H. thielei ${ }^{\mathrm{a}}$ & Cold & $3.14 \times 10^{5}$ & $0.88 \times 10^{5}$ & $0.06 \times 10^{5}$ & $0.06 \times 10^{5}$ \\
\hline N. nodastrella ${ }^{\mathrm{a}}$ & Cold & $4.83 \times 10^{5}$ & $1.55 \times 10^{5}$ & $0.11 \times 10^{5}$ & $0.09 \times 10^{5}$ \\
\hline
\end{tabular}


Nodastrella nodastrella (5 nucleotide sequences) and Higginsia thielei (1 nucleotide sequence) (Fig. 1, Table 2). Different methods (NJ and RaxML) resulted in similar tree topologies (no significant difference between them in $90 \%$ of 10000 permutations) for both nucleotides and amino acids. Therefore, only the results of the RaxML trees will be described in the following paragraphs.

Sequences of sponge-associated AOA retrieved from excised DGGE bands (Figs. S2b \& S3b in the supplement at www.int-res.com/articles/suppl/a068 p215_supp.pdf) grouped with sequences retrieved from other cold- and warm-water sponges, corals, sediment and water (Fig. 1). All archaeal amoA sequences obtained corresponded to the Thaumarchaeota group. Phylogenetic analysis revealed 6 wellsupported clusters (bootstrap value $\geq 70 \%$ ), some of them including the sequences obtained in this study. Cluster 1 includes sequences from the cold-water sponge Nodastrella nodastrella and sequences from water surrounding Halisarca caerulea, but also sequences from other cold- and warm-water marine sponges and sequences from corals and water of many different origins. We found $99 \%$ identity between a nucleotide sequence present in water surrounding $H$. caerulea (Water1_B27) and a sequence retrieved from the marine sponge Siphonochalina sp. collected in the Coral Sea (Australia). Another sequence found in water (Water1_B27) was identical (100\% similarity) to a sequence retrieved from a warm-water coral (Fungia granulosa). Cluster 2 includes amoA sequences retrieved from the Mediterranean sponge Agelas oroides and sequences from a warm-water coral (Porites astreoides, Caribbean) and a warm-water sponge (Luffariella sp., Coral Sea). Cluster 3 includes amo $A$ sequences retrieved from $H$. caerulea and the surrounding water and sequences retrieved from $N$. nodastrella and Higginsia thielei. In this cluster, there are also sequences retrieved from the cultivated AOA Nitrosopumilus maritimus. Also archaeal amoA sequences retrieved from a warm-water coral (Diploria

Table 2. Number of nucleotide (nuc.) and amino-acid (a.a.) sequences determined by PCR-DGGE-sequencing in the warm-water sponge Halisarca caerulea and the cold-water sponges Higginsia thielei and Nodastrella nodastrella. AOA: ammonia-oxidizing Archaea; AOB: ammonia-oxidizing Bacteria

\begin{tabular}{|lcccc|} 
Sample & AOA nuc. & AOA a.a. & AOB nuc. & AOB a.a. \\
\hline H. caerulea & 8 & 6 & 3 & 2 \\
H. thielei & 1 & 1 & 4 & 4 \\
N. nodastrella & 5 & 4 & 10 & 8 \\
\hline
\end{tabular}

strigosa, Caribbean), a warm-water sponge (Hymeniacidon heliophila, Atlantic), a cold-water sponge (Phakelia ventilabrum, Atlantic) and sequences retrieved from water and sediment are part of this cluster. Clusters 4, 5 and 6 do not include any amoA sequences retrieved from $H$. caerulea, $H$. thielei, or $N$. nodastrella. These clusters include mainly sequences from other warm-water sponges and corals. Archaeal amo $A$ gene sequences from $H$. caerulea, $H$. thielei and $N$. nodastrella showed 82 to $94 \%$ sequence identity (90 to $96 \%$ on an amino-acid level) to the amoA sequence of $N$. maritimus and 74 to $79 \%$ identity (92 to $93 \%$ on an amino-acid level) to the amoA sequence of 'Candidatus Cenarchaeum symbiosum'. The presence of silent mutations in different nucleotide sequences resulted in the reduced amino-acid diversity of 6 different amino-acid sequences in $H$. caerulea, 4 in N. nodastrella and 1 in $H$. thielei (Table 2, Fig. S4 in the supplement at www.int-res.com/articles/suppl/ a068p215_supp.pdf).

\section{Diversity of sponge-associated AOB}

Higher bacterial diversity was found in Nodastrella nodastrella (10 different nucleotide sequences) than in Higginsia thielei (4 nucleotide sequences) and Halisarca caerulea (3 nucleotide sequences) (Fig. 2, Table 2). Similarly, as for Archaea, description of diversity of sponge-associated AOB is only described for RaxML trees.

Sequences of sponge-associated AOB retrieved from excised DGGE bands (Figs. S2a \& S3a in the supplement) were grouped in 10 well-supported clusters (bootstrap value $\geq 70 \%$; Fig. 2). AmoA sequences retrieved from Halisarca caerulea fell into 2 clusters (Clusters 5 and 9) which were closely related to sequences derived from the tropical sponges $M y-$ cale laxissima and Ircinia strobilina. In both clusters, sequences retrieved from $H$. caerulea (Hal2_B24 and Hal3_B2) were highly similar to sequences from $M y$ cale laxissima (99\% identity). In Cluster 9, $99 \%$ identity was also found between nucleotide sequences of H. caerulea (Hal2_B24) and the surrounding water (Water2_B5). AmoA sequences retrieved from Nodastrella nodastrella and Higginsia thielei fell into 4 clusters (Clusters 1, 3, 6 and 8) and were closely related to published sequences of the sponges Polymastia cf. corticata (Cluster 1) and Dysidea avara (Cluster 3). In Clusters 6 and 8, identical sequences (100\% identity) were found in $H$. thielei and N. nodastrella. In Cluster 6 , these were also identical to a sequence found in cold water from the Pacific. Clusters 2, 4, 7, and 10 did 

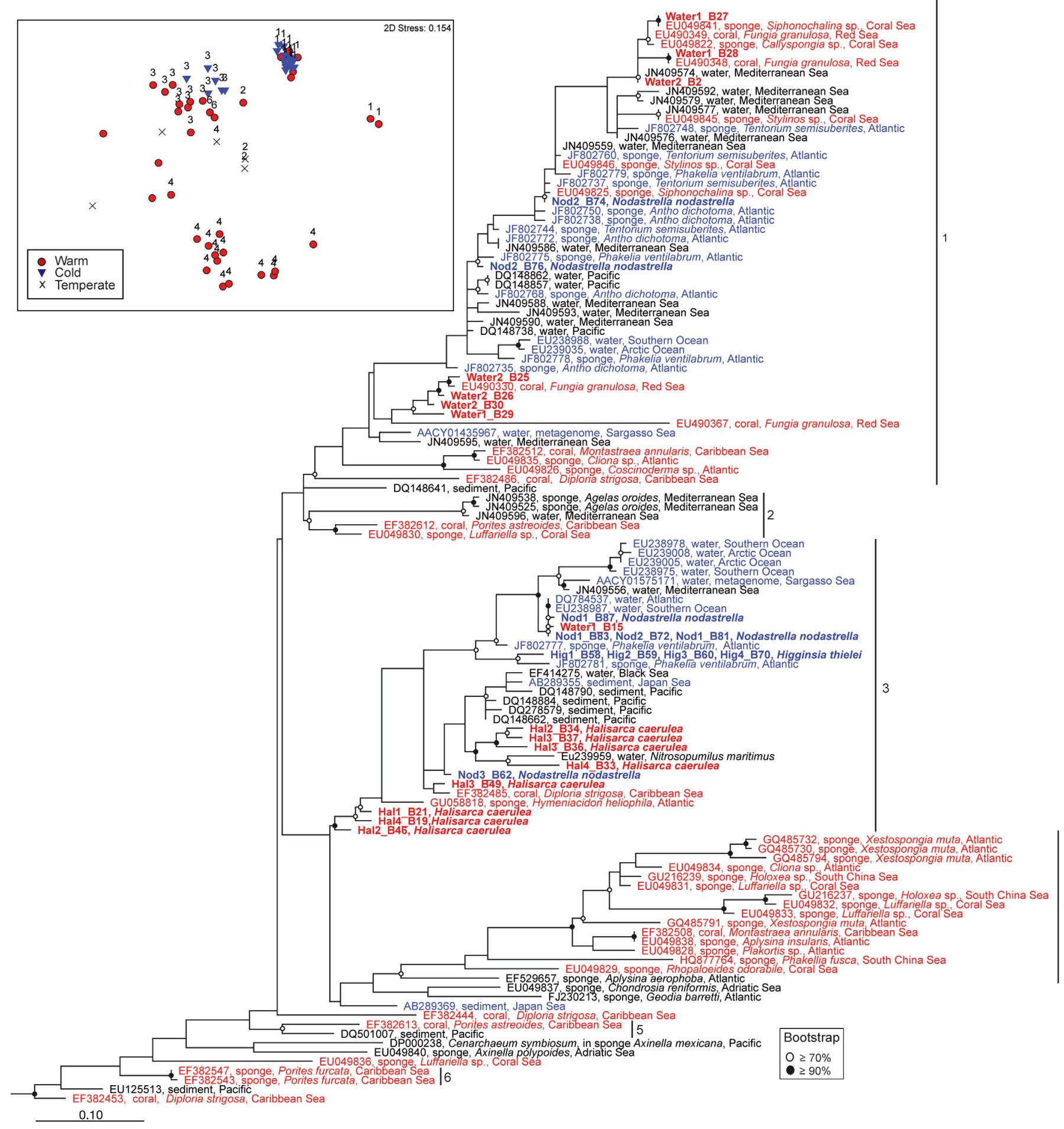

Fig. 1. Maximum-likelihood tree based on nucleotide sequences of amoA genes of Thaumarchaeota retrieved from sponges, corals, sediment and water. Sequences derived from the present study are shown in bold. Red-coloured sequences originate from habitats with warm-water temperatures (winter temperatures $>18^{\circ} \mathrm{C}$ ) and blue-coloured sequences originate from habitats with cold-water temperatures (summer temperatures $<12^{\circ} \mathrm{C}$ ); sequences which do not fit in these categories (temperate) are in black. Open circles: bootstrap values $\geq 70 \%$; filled circles: bootstrap values $\geq 90 \%$. Scale bar indicates $10 \%$ sequence divergence. The out-group (not shown) contained amoA sequences of Thaumarchaeota isolated from warm-water sediments (DQ5010xx), cold-water sediments (EU885xxx) and the corals Porites astreoides and Colpophyllia natans (EF382xxx). Inset: a multidimensional scaling plot of the distance matrix underlying the tree (only sponges), with numbers referring to the identified clusters 


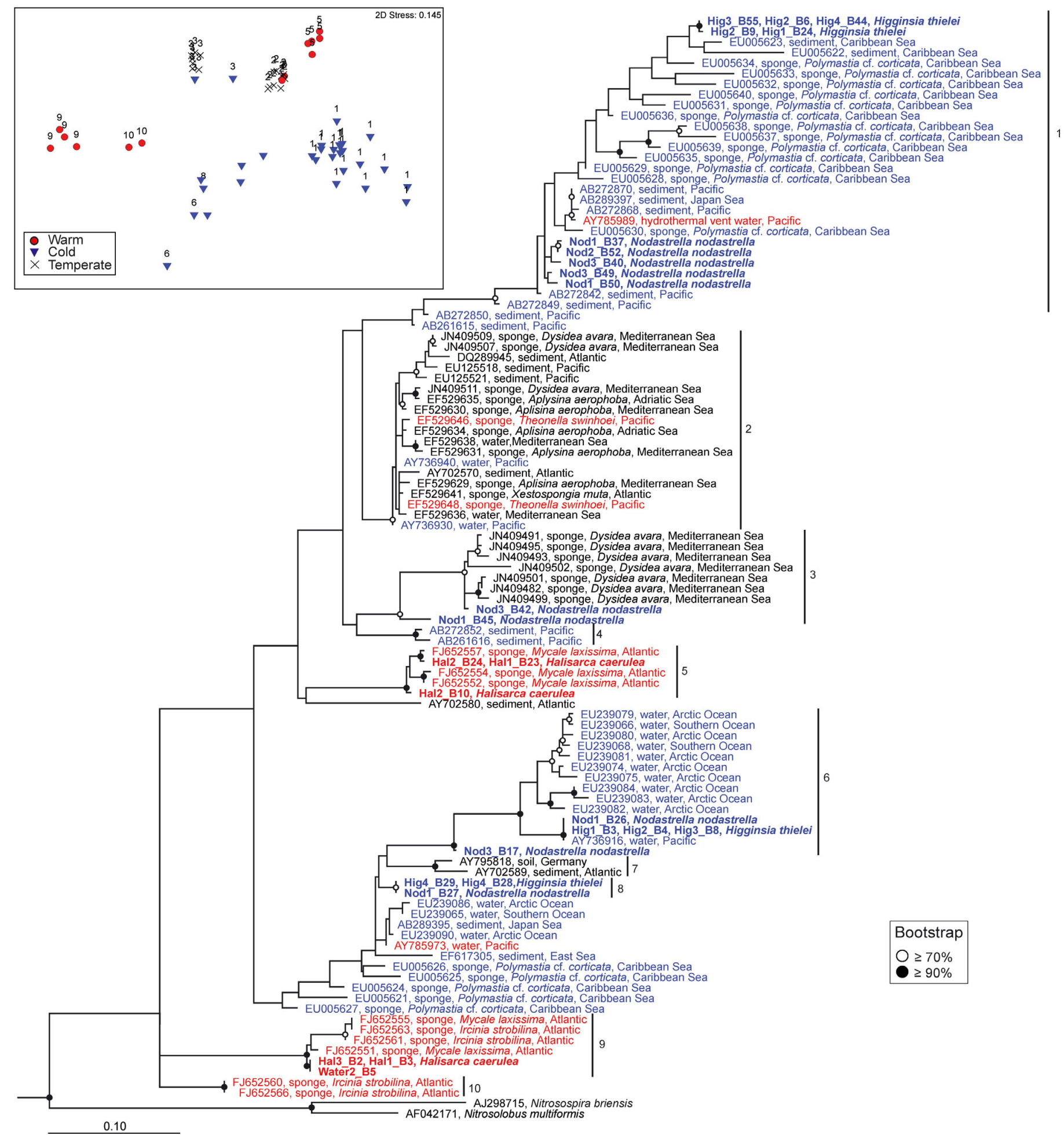

Fig. 2. Maximum-likelihood tree based on nucleotide sequences of amoA genes of Betaproteobacteria retrieved from sponges, sediment and water. Sequences derived from this study are shown in bold. Red-coloured sequences originate from habitats with warm-water temperatures (winter temperatures $>18^{\circ} \mathrm{C}$ ) and blue-coloured sequences originate from habitats with cold-water temperatures (summer temperatures $<12^{\circ} \mathrm{C}$ ); sequences which do not fit in these categories (temperate) are in black. Open circles: bootstrap values $\geq 70 \%$; filled circles: bootstrap values $\geq 90 \%$. Scale bar indicates $10 \%$ sequence divergence. The out-group (not shown) contained amoA sequences of cultivated Nitrosomonas spp. and Nitrosospira spp. Inset: a multidimensional scaling plot of the distance matrix underlying the tree (sponge species only), with numbers referring to the identified clusters 
not contain any of our own sequences, but 2 of these clusters ( 2 and 10) did contain sequences retrieved from sponges. Bacterial amoA gene sequences retrieved from $H$. caerulea, $H$. thielei and $N$. nodastrella showed 73 to $77 \%$ sequence identity (88 to $91 \%$ on an amino-acid level) to the amoA sequence of the cultured AOB Nitrosospira briensis, and 75 to $77 \%$ sequence identity (87 to $93 \%$ on an amino-acid level) to the amoA sequence of Nitrosolobus multiformis. For $H$. caerulea and N. nodastrella, amino-acid trees revealed lower diversity than nucleotide trees, showing 8 different amino-acid sequences in N. nodastrella and 2 in $H$. caerulea (Table 2, Fig. S5 in the supplement at www.int-res.com/articles/suppl/a068 p215_supp.pdf). In $H$. thielei each different nucleotide sequence was also a different amino-acid sequence (4 different amino-acid sequences were retrieved). Overall, similar clustering was observed between nucleotide and amino-acid trees.

\section{Effect of host species and temperature on AOA and AOB diversity}

Two-way nested PERMANOVA and ANOSIM tests were performed using all non-redundant amo $A$ sequences retrieved from sponges and available in GenBank up to September 2012. For Archaea, both tests showed a significant effect of sponge species on the structure of archaeal amo $A$ trees $(p \leq 0.01$ for nucleotides and amino acids; Table 3). Taking into account the effect of species, temperature also significantly influenced the distribution of sponge archaeal amo $A$ sequences in the nucleotide trees $(p=0.0001$, PERMANOVA test), although the effect of temperature was not very strong (only slightly significant in cases when all sponge sequences were considered) in the amino-acid tree $(0.037<\mathrm{p}<0.054$; Table 3$)$. The ANOSIM test was not very strong due to the low number of permutations. For Bacteria, sponge species significantly affected the structure of amoA nucleotide trees $(\mathrm{p}<0.05)$, but not amino-acid trees ( $p>0.05$ ) (Table 3). Temperature significantly affected the distribution of sponge bacterial amo $A$ in nucleotide and amino-acid trees ( $\mathrm{p} \leq 0.001)$.

PERMANOVA tests done on the distribution of archaeal and bacterial amoA genes in relation to habitat type (sponge, coral, sediment and water) revealed that for both Archaea and Bacteria, habitat and temperature have a highly significant effect on the distribution of AOA and AOB ( $p<0.0001$; Table S3 in the supplement at www.int-res.com/articles/suppl /a068p215_supp.pdf). Further pair-wise tests suggested that the distribution of bacterial amoA did not differ significantly between sponge and sediment, while the distribution of archaeal amoA did not differ significantly between sponge and water (not shown). However, these tests are not statistically strong due to an unbalanced dataset and should, therefore, only be used as an indication.

\section{DISCUSSION}

Our results reinforce the notion that sponges harbour microbial organisms with metabolisms that are important to the $\mathrm{N}$-cycle in tropical and cold-water coral reef communities (see reviews by Taylor et al. 2007 and Hentschel et al. 2012). Both bacterial and archaeal amoA genes were found in Halisarca caerulea, Higginsia thielei and Nodastrella nodastrella, showing that $\mathrm{AOB}$, as well as $\mathrm{AOA}$, reside in these sponges. In terms of abundance, numbers of AOA were higher than those of AOB in all 3 studied sponge species (on average 5- to 16-fold more AOA than AOB). In 3 other cold-water sponge species, the numbers of AOA per gram of sponge were about 150 times to $4 \times 10^{5}$ times higher than those of AOB (Radax et al. 2012). AOA were also found to be the main ammonia-oxidizing microbes in the warm- 
water sponge Phakelia fusca (Han et al. 2012). Our results suggest that AOA may be responsible for a major part of the ammonia oxidation, not only in cold-water sponges, as previously suggested by Radax et al. (2012), but also in tropical sponges. Archaeal amoA genes in the water surrounding $H$. caerulea were about 2 orders of magnitude higher than bacterial amoA genes. Previous studies describe archaeal amoA copy numbers in Atlantic and Mediterranean waters as being 1 to 3 orders of magnitude higher than those of bacterial amoA (Wuchter et al. 2006, De Corte et al. 2009), and up to 4 orders of magnitude higher in the Pacific (Mincer et al. 2007). Our data support the idea that AOA play a major role in nitrification, not only in the ocean, but also in sponges.

\section{Microbial abundance}

In terms of total microbial abundance, Bacteria were seen to dominate the microbial community in Halisarca caerulea, showing much higher densities than Archaea. The same has been observed in Higginsia thielei and Nodastrella nodastrella (Van Duyl et al. 2008). Bacteria were also seen to dominate the microbial community in Agelas oroides and Chondrosia reniformis (Ribes et al. 2012) and in Phakellia fusca (Han et al. 2012). However, in other sponges, Archaea were more dominant than Bacteria (Margot et al. 2002, Pape et al. 2006). The use of different probes in different studies may be one of the reasons for the differences in abundance of Archaea versus Bacteria in sponges. In addition, due to the lack of data on microbial abundance of many sponge species, as recently emphasized by Simister et al. (2012), a general trend is difficult to find.

Bacterial and total archaeal abundance varied considerably between specimens of Halisarca caerulea (as shown by the large standard deviation observed). Variability in bacterial abundance was larger than described for Higginsia thielei and Nodastrella nodastrella (Van Duyl et al. 2008). Differences in microbial abundance between specimens could be due to sampling of different tissues within a sponge. In the sponge Polymastia cf. corticata, high variability in bacterial and archaeal communities was associated with different tissue sections (Meyer \& Kuever 2008).

In Halisarca caerulea, about $1.3 \%$ of FISH-positive microorganisms were total Archaea (Euryarchaea + Thaumarchaea), from which less than half were Thaumarchaea. This value is much lower than for Nodastrella nodastrella and Higginsia thielei. In these 2 cold-water sponges 11 to $18 \%$ of the DAPI counts were total Archaea, with a dominance of Thaumarchaea (Van Duyl et al. 2008). The presence of Euryarchaea in marine sponges has been reported in a few studies. Euryarchaea were detected in Rhopaloeides odorabile (Webster et al. 2001) and 3 other sponges (Holmes \& Blanch 2007) from Australia. Also Agelas oroides (Ribes et al. 2012) hosted Euryarchaea. Apparently, Euryarchaea also form a substantial fraction of the total archaeal community in H. caerulea.

\section{Diversity of sponge-associated AOA and AOB}

Archaeal and bacterial amoA sequences retrieved from Halisarca caerulea, Nodastrella nodastrella and Higginsia thielei were compared with sequences retrieved from other sponges, corals and environmental samples (sediment, water). Archaeal amoA sequences were distinct from those found in other sponges (Bayer et al. 2008, Meyer \& Kuever 2008, Steger et al. 2008, Hoffmann et al. 2009, LópezLegentil et al. 2010, Turque et al. 2010, Liu et al. 2011, Han et al. 2012, Radax et al. 2012, Ribes et al. 2012). The closest relative to sequences retrieved from the tropical sponge $H$. caerulea was from the coral Diploria strigosa (Beman et al. 2007), while amoA sequences from water surrounding the sponge were similar to sequences retrieved from the warmwater sponge Siphonochalina sp. (Steger et al. 2008) and the warm-water coral Fungia granulosa (Siboni et al. 2008). AOA in the cold-water sponge $H$. thielei were closest to AOA found in the cold-water sponge Phakelia ventilabrum (Radax et al. 2012), and the closest relative of archaeal sequences retrieved from $N$. nodastrella were found in water from the Antarctic (Kalanetra et al. 2009). There was no clear biogeographic effect, with many of the sponge-derived sequences forming large clusters comprising sequences from many different locations, such as the Red Sea, Atlantic, Caribbean, Mediterranean, China Sea and more. A widespread distribution of archaeal sequences retrieved from sponges has also been observed in earlier studies (Steger et al. 2008, Ribes et al. 2012). The 6 well-supported clusters contained, not only amoA sequences retrieved from sponges, but also sequences from corals, sediments and/or water. No clear sponge-specific clusters were observed either. Cluster 4 included, however, mainly sequences retrieved from sponges, excluding 1 sequence from a coral. It seems, therefore, that most archaeal communities in sponges may be acquired, 
above all, horizontally via sediment or water. Nevertheless, Archaea have also been found in sponge larvae and gametes, indicating that some AOA may be vertically transmitted (see review by Webster \& Taylor 2012 and references therein). The high similarity between archaeal 16S rRNA sequences retrieved from the sponge Polymastia cf. corticata and sequences from other sponge species (Meyer \& Kuever 2008) supports the existence of sponge-specific clusters and vertically acquired Archaea within sponges. The existence of sponge-specific associated Archaea has also been suggested for other sponge species (Preston et al. 1996, Holmes \& Blanch 2007, Bayer et al. 2008, Hoffmann et al. 2009, Turque et al. 2010, Radax et al. 2012).

Bacterial amoA sequences retrieved from Halisarca caerulea showed high similarity to sequences retrieved from the tropical sponges Mycale laxissima and Ircinia strobilina (Mohamed et al. 2010), while sequences retrieved from Higginsia thielei and Nodastrella nodastrella were similar to sequences obtained from the deep-water sponge Polymastia corticata (Meyer \& Kuever 2008). The closest relatives of sequences retrieved from the tropical sponge $H$. caerulea were found in the sponge M. laxissima (Mohamed et al. 2010) and in the water surrounding $H$. caerulea. Identical AOB sequences were found in $H$. thielei, N. nodastrella and in cold water from the Pacific (O'Mullan \& Ward 2005). Similar to the archaeal amoA tree, no clear biogeographic effect is seen in the AOB tree. Sequences retrieved from sponges fall in clusters containing sequences from different locations. Cluster 2 includes sequences from sponges collected in the Mediterranean, Adriatic, Atlantic and Pacific. And AOB sequences retrieved from $N$. nodastrella in Cluster 3 group with sequences from Dysidea avara from the Mediterranean. Such diverse distribution of bacterial communities has also been reported in earlier studies, with geographically distant sponges showing similar sponge-associated Bacteria (Montalvo \& Hill 2011, Yang et al. 2011, Ribes et al. 2012). Two of the wellsupported clusters (Clusters 1 and 2) contained mainly sequences from sponges and sediment, while Cluster 6 contained only sequences from sponges and water. High similarity in bacterial composition between sediment and sponges has also been previously reported (Turque et al. 2008). The distribution of bacterial amoA does not seem to differ significantly between sponge and sediment, as suggested by the PERMANOVA test. This fact supports the idea that bacterial communities may be horizontally acquired via the sediment. The fact that 1 clus- ter contains only sequences from $H$. thielei, $N$. nodastrella and water, suggests the acquisition of AOB via water as well. In addition, several clusters contain only sequences retrieved from sponges, suggesting the existence of sponge-specific AOB. The grouping of sequences retrieved from $H$. thielei and $N$. nodastrella in 1 cluster suggests the existence of coldwater, sponge-specific AOB. Our results corroborate earlier reports that AOB may also be vertically transmitted in sponges (Turque et al. 2008, review by Webster \& Taylor 2012 and references therein). In 3 Great Barrier reef sponges, many previously called 'sponge-specific' bacterial clusters were detected in seawater, suggesting that both vertical and horizontal transmission might operate together (Webster et al. 2010).

In general, considering the 3 species, the bacterial community was more diverse than the archaeal community. Seventeen different bacterial nucleotide sequences in contrast to 14 archaeal nucleotide sequences were retrieved from the studied sponges. However, it should be taken into account that some Bacteria may present multiple copies of the amoA gene (Norton et al. 2002), which will influence the real number of different nucleotide sequences found. It should also be kept in mind that the sequences presented here were obtained by DGGE analysis of PCR products, and our diversity assessment is therefore based on very short fragments. In addition, primerintroduced amplification bias cannot be excluded as one of the reasons for the observed differences in diversity of AOA and AOB in relation to other studies. The primers used may also have influenced the formation of the distinct sequence clusters.

\section{Effect of temperature on AOA and AOB diversity}

Temperature significantly affected the distribution of sponge sequences in both archaeal and bacterial amoA trees. The effect of temperature on the composition of bacterial and archaeal assemblages has been mentioned in several studies. In the Mediterranean sponge Aplysina aerophoba, temperature partially explained the increase in ammonium excretion rates from spring to the end of summer (Bayer et al. 2008), suggesting that seasonal differences in community composition of sponge-associated microorganisms may be responsible for the observed variations. In fact, water temperature was the environmental variable that best explained spring, summer and winter archaeal assemblage structure in freshwater lakes (Auguet et al. 2011). Also in sulphurous 
lakes (Casamayor et al. 2001, Llirós et al. 2008), North Sea waters (Wuchter et al. 2006, Herfort et al. 2007) and estuarine sediments (Sahan \& Muyzer 2008) temperature was seen to control the diversity of Bacteria and Archaea (including AOB and AOA). Nevertheless, in Mediterranean Sea waters (De Corte et al. 2009) and in soil (Tourna et al. 2008), no effect of temperature on bacterial or archaeal amoA diversity was observed, indicating that other environmental factors also affect the presence of nitrifying microorganisms.

In bacterial amoA trees (nucleotide and amino-acid trees) clear clustering could be seen between sponge sequences retrieved from habitats with similar temperatures (cold, warm, or temperate). Phylogenetically similar sponge-associated bacterial communities originating from similar habitats have been reported in earlier studies. The bacterial communities associated with the geographically distant warmwater sponges Xestospongia muta and X. testudinaria were seen to be similar (Montalvo \& Hill 2011). On the other hand, sponge-associated Bacteria from the shallow Caribbean Sea were found to be significantly distinct from Bacteria retrieved from sponges from deep-water environments of the Caribbean Sea. Therefore, our results suggest the existence of temperature-related, sponge-specific associated Bacteria. In archaeal amoA trees the effect of temperature in structuring the distribution of AOA was also significant, although in terms of the amino-acid tree the temperature effect was not as strong as for the bacterial tree. Archaeal amoA sequences from habitats with similar temperature conditions tended to group together, but in smaller sub-clusters. In earlier studies, archaeal phylotypes retrieved from cold-water sponges were found to be related to sequences from deeper and colder waters (Radax et al. 2012). Also, distinct archaeal communities retrieved from sponges from the same area suggested that environmental conditions have an effect on sponge-associated microbial communities (Turque et al. 2010). Overall, our results suggest the existence of sponge-associated archaeal and bacterial communities adapted to different temperatures.

The relatively high similarity between the microbial community of Nodastrella nodastrella and Higginsia thielei (often grouping in the same cluster) is quite interesting considering the fact that they are phylogenetically distant species. $H$. thielei belongs to the class Demospongiae, while $N$. nodastrella belongs to the class Hexactinellida. Similarities in microbial communities have often been described in closely related sponges (review by Taylor et al. 2007). Nev- ertheless, phylogenetically distant sponges (although both Demospongiae) such as Aplysina aerophoba and Theonella swinhoei were also seen to contain similar microbial communities (Hentschel et al. 2002). To the best of our knowledge, the present study describes for the first time the diversity of AOA and $\mathrm{AOB}$ in a hexactinellid sponge. Our results support the idea of a relatively uniform microbial community between distantly related sponges and suggest that temperature (rather than phylogenetic distance) determines the diversity of AOA and AOB communities in sponges.

Acknowledgements. We thank Maggy M. Nugues for collecting Halisarca caerulea in 2003, Martine M. van Oostveen for collecting $H$. caerulea in 2004 and doing CARDFISH analysis and Conny Maier for collecting Higginsia thielei and Nodastrella nodastrella in 2006. Ben Abbas developed the primer amoAf-i-BA. Laura Villanueva provided the standards for the Q-PCR calibration curves. Hans Malschaert maintained the Linux systems for running ARB software. Pieternella Luttikhuizen and 5 anonymous reviewers provided valuable comments on previous versions of this manuscript. Gerard Muyzer and Mark van Loodsrecht offered office space and facilities at TU Delft. Cold-water coral reef sponges were collected during the BIOSYS expedition funded by ALW-NWO (Grant No. 835.20.024). J.F.M.F.C. was supported by Fundação para a Ciência e a Tecnologia and Fundo Social Europeu (SFRH/BPD/34773/ 2007) and by the EU SPONGES project (FP6-COOP-CT2005-017800).

\section{LITERATURE CITED}

Altschul SF, Madden TL, Schäffer AA, Zhang J, Zhang Z, Miller W, Lipman DJ (1997) Gapped BLAST and PSIBLAST: a new generation of protein database search programs. Nucleic Acids Res 25:3389-3402

> Amann RI, Binder BJ, Olson RJ, Chisholm SW, Devereux R, Stahl DA (1990) Combination of 16S rRNA-targeted oligonucleotide probes with flow cytometry for analyzing mixed microbial populations. Appl Environ Microbiol 56: 1919-1925

Anderson MJ, Gorley RN, Clarke KR (2008) PERMANOVA + for PRIMER: guide to software and statistical methods. PRIMER-E, Plymouth

Auguet JC, Nomokonova N, Camarero L, Casamayor EO (2011) Seasonal changes of freshwater ammonia-oxidizing archaeal assemblages and nitrogen species in oligotrophic alpine lakes. Appl Environ Microbiol 77: 1937-1945

Bayer K, Schmitt S, Hentschel U (2008) Physiology, phylogeny and in situ evidence for bacterial and archaeal nitrifiers in the marine sponge Aplysina aerophoba. Environ Microbiol 10:2942-2955

Beman JM, Roberts KJ, Wegley L, Rohwer F, Francis CA (2007) Distribution and diversity of archaeal ammonia monooxygenase genes associated with corals. Appl Environ Microbiol 73:5642-5647

Casamayor EO, Muyzer G, Pedrós Alió C (2001) Composition and temporal dynamics of planktonic archaeal 
assemblages from anaerobic sulfurous environments studied by $16 \mathrm{~S}$ rDNA denaturing gradient gel electrophoresis and sequencing. Aquat Microb Ecol 25:237-246

Cheng N, Fang Z, Huang H, Fang Z, Wu X, Bao S (2008) Phylogenetic diversity of bacteria and archaea associated with the marine sponge Pachychalina sp. Pol J Ecol 56:505-510

- Clarke KR (1993) Non-parametric multivariate analysis of changes in community structure. Aust J Ecol 18:117-143

Collin R, Díaz MC, Norenburg J, Rocha RM and others (2005) Photographic identification guide to some common marine invertebrates of Bocas Del Toro, Panama. Caribb J Sci 41:638-707

> Corredor JE, Wilkinson CR, Vicente VP, Morell JM, Otero E (1988) Nitrate release by Caribbean reef sponges. Limnol Oceanogr 33:114-120

> Daims H, Brühl A, Amann R, Schleifer KH, Wagner M (1999) The domain-specific probe EUB338 is insufficient for the detection of all Bacteria: development and evaluation of a more comprehensive probe set. Syst Appl Microbiol 22: 434-444

> De Corte D, Yokokawa T, Varela MM, Agogué H, Herndl GJ (2009) Spatial distribution of Bacteria and Archaea and amoA gene copy numbers throughout the water column of the eastern Mediterranean Sea. ISME J 3:147-158

> De Goeij JM, Van den Berg H, Van Oostveen MM, Epping EHG, Van Duyl FC (2008) Major bulk dissolved organic carbon (DOC) removal by encrusting coral reef cavity sponges. Mar Ecol Prog Ser 357:139-151

Diaz MC, Rützler K (2001) Sponges: an essential component of Caribbean coral reefs. Bull Mar Sci 69:535-546

> Diaz MC, Ward BB (1997) Sponge-mediated nitrification in tropical benthic communities. Mar Ecol Prog Ser 156: 97-107

> Diaz MC, Smith KP, Rützler K (2004) Sponge species richness and abundance as indicators of mangrove epibenthic community health. Atoll Res Bull 518:1-11

Dohrmann M, Göcke C, Reed J, Janussen D (2012) Integrative taxonomy justifies a new genus, Nodastrella gen. nov., for North Atlantic 'Rossella' species (Porifera: Hexactinellida: Rossellidae). Zootaxa 3383:1-13

- Hallam SJ, Mincer TJ, Schleper C, Preston CM, Roberts K, Richardson PM, DeLong EF (2006) Pathways of carbon assimilation and ammonia oxidation suggested by environmental genomic analyses of marine Crenarchaeota. PLoS Biol 4:e95

$>$ Han M, Liu F, Zhang F, Li Z, Lin H (2012) Bacterial and archaeal symbionts in the South China Sea sponge Phakellia fusca: community structure, relative abundance, and ammonia-oxidizing populations. Mar Biotechnol (NY) 14:701-713

Hentschel U, Hopke J, Horn M, Friedrich AB, Wagner M, Hacker J, Moore BS (2002) Molecular evidence for a uniform microbial community in sponges from different oceans. Appl Environ Microbiol 68:4431-4440

> Hentschel U, Piel J, Degnan SM, Taylor MW (2012) Genomic insights into the marine sponge microbiome. Nat Rev Microbiol 10:641-654

Herfort L, Schouten S, Abbas B, Veldhuis MJW and others (2007) Variations in spatial and temporal distribution of Archaea in the North Sea in relation to environmental variables. FEMS Microbiol Ecol 62:242-257

Hoffmann F, Radax R, Woebken D, Holtappels M and others (2009) Complex nitrogen cycling in the sponge Geodia barretti. Environ Microbiol 11:2228-2243
Holmes B, Blanch H (2007) Genus-specific associations of marine sponges with group I crenarchaeotes. Mar Biol 150:759-772

Hooper JNA, Van Soest RWM (2002) Systema Porifera: a guide to the classification of Sponges. Kluwer Academic/Plenum Publishers, New York, NY

$>$ Hornek R, Pommerening-Röser A, Koops HP, Farnleiter AH, Kreuzinger N, Kirschner A, Mach RL (2006) Primers containing universal bases reduce multiple amoA gene specific DGGE band patterns when analysing the diversity of beta-ammonia oxidizers in the environment. J Microbiol Methods 66:147-155

> Hyman MR, Arp DJ (1992) ${ }^{14} \mathrm{C}_{2} \mathrm{H}_{2}$ and ${ }^{14} \mathrm{CO}_{2}$-labeling studies of the de novo synthesis of polypeptides by Nitrosomonas europaea during recovery from acetylene and light inactivation of ammonia monooxygenase. J Biol Chem 267:1534-1545

Jiménez E, Ribes M (2007) Sponges as a source of dissolved inorganic nitrogen: nitrification mediated by temperate sponges. Limnol Oceanogr 52:948-958

Kalanetra KM, Bano N, Hollibaugh JT (2009) Ammonia-oxidizing Archaea in the Arctic Ocean and Antarctic coastal waters. Environ Microbiol 11:2434-2445

Klotz MG, Alzerreca JJ, Norton JM (1997) A gene encoding a membrane protein exists upstream of the $a m o A / a m o B$ genes in ammonia-oxidizing bacteria; a third member of the amo operon? FEMS Microbiol Lett 150:65-73

Kobluk DR, Van Soest RWM (1989) Cavity-dwelling sponges in a southern Caribbean coral reef and their paleontological implications. Bull Mar Sci 44:1207-1235

> Könneke M, Bernhard AE, de la Torre JR, Walker CB, Waterbury JB, Stahl DA (2005) Isolation of an autotrophic ammonia-oxidizing marine archaeon. Nature 437:543-546

> Liu F, Han M, Zhang F, Zhang B, Li Z (2011) Distribution and abundance of archaea in South China Sea sponge Holoxea sp. and the presence of ammonia-oxidizing Archaea in sponge cells. Evid Based Complement Alternat Med 2011:723696

> Llirós M, Casamayor EO, Borrego CM (2008) High archaeal richness in the water column of a freshwater sulfurous karstic lake along an interannual study. FEMS Microbiol Ecol 66:331-342

López-Legentil S, Erwin PM, Pawlik JR, Song B (2010) Effects of sponge bleaching on ammonia-oxidizing Archaea: distribution and relative expression of ammonia monooxygenase genes associated with the barrel sponge Xestospongia muta. Microb Ecol 60:561-571

Ludwig W, Strunk O, Westram R, Richter L and others (2004) ARB: a software environment for sequence data. Nucleic Acids Res 32:1363-1371

Margot H, Acebal C, Toril E, Amils R, Fernández JL (2002) Consistent association of crenarchaeal Archaea with sponges of genus Axinella. Mar Biol 140:739-745

> McTavish H, Fuchs JA, Hooper AB (1993) Sequence of the gene coding for ammonia monooxygenase in Nitrosomonas europaea. J Bacteriol 175:2436-2444

> Meyer B, Kuever J (2008) Phylogenetic diversity and spatial distribution of the microbial community associated with the Caribbean deep-water sponge Polymastia cf. corticata by $16 \mathrm{~S}$ rRNA, aprA, and amoA gene analysis. Microb Ecol 56:306-321

- Mincer TJ, Church MJ, Taylor LT, Preston C, Karl DM, DeLong EF (2007) Quantitative distribution of presumptive archaeal and bacterial nitrifiers in Monterey Bay and 
the North Pacific Subtropical Gyre. Environ Microbiol 9: 1162-1175

Mohamed NM, Enticknap JJ, Lohr JE, McIntosh SM, Hill RT (2008) Changes in bacterial communities of the marine sponge Mycale laxissima on transfer into aquaculture. Appl Environ Microbiol 74:1209-1222

Mohamed NM, Saito K, Tal Y, Hill RT (2010) Diversity of aerobic and anaerobic ammonia-oxidizing bacteria in marine sponges. ISME J 4:38-48

> Montalvo NF, Hill RT (2011) Sponge-associated bacteria are strictly maintained in two closely related but geographically distant sponge hosts. Appl Environ Microbiol 77 : 7207-7216

> Norton JM, Alzerreca JJ, Suwa Y, Klotz MG (2002) Diversity of ammonia monooxygenase operon in autotrophic ammonia-oxidizing bacteria. Arch Microbiol 177: 139-149

$>$ O'Mullan GD, Ward BB (2005) Relationship of temporal and spatial variabilities of ammonia-oxidizing bacteria to nitrification rates in Monterey Bay, California. Appl Environ Microbiol 71:697-705

Pape T, Hoffmann F, Queric NV, Von Juterzenka K, Reitner J, Michaelis W (2006) Dense populations of Archaea associated with the demosponge Tentorium semisuberites Schmidt, 1870 from Arctic deep-waters. Polar Biol 29:662-667

> Pernthaler A, Pernthaler J, Amann R (2002) Fluorescence in situ hybridization and catalyzed reporter deposition for the identification of marine bacteria. Appl Environ Microbiol 68:3094-3101

> Pester M, Schleper C, Wagner M (2011) The Thaumarchaeota: an emerging view of their phylogeny and ecophysiology. Curr Opin Microbiol 14:300-306

Preston CM, Wu KY, Molinski TF, Delong EF (1996) A psychrophilic crenarchaeon inhabits a marine sponge: Cenarchaeum symbiosum gen. nov., sp. nov. Proc Natl Acad Sci USA 93:6241-6246

Radax R, Hoffmann F, Rapp HT, Leininger S, Schleper C (2012) Ammonia-oxidizing archaea as main drivers of nitrification in cold water sponges. Environ Microbiol 14: 909-923

Reitner J, Hoffmann F (2003) Porifera-Zonierungen in Kaltwasser-Korallenriffen (Sula-Rücken, Norwegen). In: Gradstein SR, Willmann R, Zizka G (eds) Biodiversitätsforschung: die Entschlüsselung der Artenvielfalt in Raum und Zeit. Kleine Senckenberg-Reihe 45, Schweizerbart'sche Verlagsbuchhandlung, Stuttgart

Ribes M, Jiménez E, Yahel G, López-Sendino P and others (2012) Functional convergence of microbes associated with temperate marine sponges. Environ Microbiol 14: 1224-1239

Sahan E, Muyzer G (2008) Diversity and spatio-temporal distribution of ammonia-oxidizing Archaea and Bacteria in sediments of the Westerschelde estuary. FEMS Microbiol Ecol 64:175-186

> Scheffers SR, Nieuwland G, Bak RPM, Van Duyl FC (2004) Removal of bacteria and nutrient dynamics within the coral reef framework of Curaçao (Netherlands Antilles). Coral Reefs 23:413-422

Schläppy ML, Schottner SI, Lavik G, Kuypers MMM, De Beer D, Hoffmann F (2010) Evidence of nitrification and denitrification in high and low microbial abundance sponges. Mar Biol 157:593-602

Siboni N, Ben-Dov E, Sivan A, Kushmaro A (2008) Global distribution and diversity of coral-associated Archaea and their possible role in the coral holobiont nitrogen cycle. Environ Microbiol 10:2979-2990

Simister RL, Deines P, Botté ES, Webster NS, Taylor MW (2012) Sponge-specific clusters revisited: a comprehensive phylogeny of sponge-associated microorganisms. Environ Microbiol 14:517-524

Southwell MW, Weisz JB, Martens CS, Lindquist N (2008) In situ fluxes of dissolved inorganic nitrogen from the sponge community on Conch Reef, Key Largo, Florida. Limnol Oceanogr 53:986-996

Stamatakis A (2006) RAxML-VI-HPC: maximum likelihoodbased phylogenetic analyses with thousands of taxa and mixed models. Bioinformatics 22:2688-2690

Steger D, Ettinger-Epstein P, Whalan S, Hentschel U, De Nys R, Wagner M, Taylor MW (2008) Diversity and mode of transmission of ammonia-oxidizing archaea in marine sponges. Environ Microbiol 10:1087-1094

Taylor MW, Radax R, Steger D, Wagner M (2007) Spongeassociated microorganisms: evolution, ecology, and biotechnological potential. Microbiol Mol Biol Rev 71: 295-347

Teira E, Reinthaler T, Pernthaler A, Pernthaler J, Herndl GJ (2004) Combining catalyzed reporter depositionfluorescence in situ hybridization and microautoradiography to detect substrate utilization by bacteria and archaea in the deep ocean. Appl Environ Microbiol 70: 4411-4414

> Tourna M, Freitag TE, Nicol GW, Prosser JI (2008) Growth, activity and temperature responses of ammonia-oxidizing archaea and bacteria in soil microcosms. Environ Microbiol 10:1357-1364

Turque AS, Cardoso AM, Silveira CB, Vieira RP and others (2008) Bacterial communities of the marine sponges Hymeniacidon heliophila and Polymastia janeirensis and their environment in Rio de Janeiro, Brazil. Mar Biol 155: 135-146

> Turque AS, Batista D, Silveira CB, Cardoso AM and others (2010) Environmental shaping of sponge-associated archaeal communities. PLoS ONE 5:e15774

Vacelet J, Donadey C (1987) A new species of Halisarca (Porifera, Demospongiae) from the Caribbean with remarks on the cytology and affinities of the genus. In: Jones WC (ed) European contribution to the taxonomy of sponges. Litho Press, Midleton

> Van Duyl FC, Scheffers SR, Thomas IM, Driscoll M (2006) The effect of water exchange on bacterioplankton depletion and inorganic nutrient dynamics in coral reef cavities. Coral Reefs 25:23-36

Van Duyl FC, Hegeman J, Hoogstraten A, Maier C (2008) Dissolved carbon fixation by sponge-microbe consortia of deep water coral mounds in the northeastern Atlantic Ocean. Mar Ecol Prog Ser 358:137-150

Van Soest RWM (1978) Marine sponges from Curacao and other Caribbean localities: Keratosa. Foundation for Scientific Research in Surinam and The Netherlands Antilles, Utrecht

Van Soest RWM, Cleary DFR, De Kluijver MJ, Lavaleye MSS, Maier C, Van Duyl FC (2007a) Sponge diversity and community composition in Irish bathyal coral reefs. Contrib Zool 76:121-142

Van Soest RWM, Van Duyl FC, Maier C, Lavaleye MSS, Beglinger EJ, Tabachnick KR (2007b) Mass occurrence of Rossella nodastrella Topsent on bathyal coral reefs of Rockall Bank, W of Ireland (Lyssacinosida, Hexactinellida). In: Custódio MR, Lôbo-Hajdu 
G, Hajdu E, Muricy G (eds) Trends in Porifera research-biodiversity, innovation and sustainability. Proc 7th Int Sponge Conf, Buzios 6-13 May 2006, Brazil, p 645-652

Van Soest RWM, Boury-Esnault N, Hooper JNA, Rützler K and others (2012) World Porifera database. Available at: www.marinespecies.org/porifera/

Wallner G, Amann R, Beisker W (1993) Optimizing fluorescent in situ hybridization with rRNA-targeted oligonucleotide probes for flow cytometric identification of microorganisms. Cytometry 14:136-143

> Webster NS, Taylor MW (2012) Marine sponges and their microbial symbionts: love and other relationships. Environ Microbiol 14:335-346

- Webster NS, Watts JEM, Hill RT (2001) Detection and phylo-

Editorial responsibility: Antje Boetius,

Bremen, Germany genetic analysis of novel crenarchaeote and euryarchaeote 16S ribosomal RNA gene sequences from a Great Barrier Reef sponge. Mar Biotechnol (NY) 3: 600-608

Webster NS, Taylor MW, Behnam F, Lücker S and others (2010) Deep sequencing reveals exceptional diversity and modes of transmission for bacterial sponge symbionts. Environ Microbiol 12:2070-2082

Wuchter C, Abbas B, Coolen MJ, Herfort L and others (2006) Archaeal nitrification in the ocean. Proc Natl Acad Sci USA 103:12317-12322

> Yang J, Sun J, Lee OO, Wong YH, Qian PY (2011) Phylogenetic diversity and community structure of sponge-associated bacteria from mangroves of the Caribbean Sea. Aquat Microb Ecol 62:231-240

Submitted: January 16, 2012; Accepted: December 9, 2012 Proofs received from author(s): February 27, 2013 